\title{
Tracing the Economic Transition of Kyrgyzstan in the Works of Prof. Dzharkinay Asanovna Musaeva (1948-2018), a Leading Female Economist
}

\author{
Nargiza ALYMKULOVA*
}

Received: November 11, 2019. Revised: December 9, 2019. Accepted: December 11, 2019.

\begin{abstract}
This paper aims to synchronize the historical developments in the economy of the Kyrgyz Republic with the works of Professor Musaeva Dzharkinay Asanovna. Prof. Musaeva, the recipient of the outstanding scholar of National Education of the Kyrgyz Republic award, was a prominent representative of the science and culture of the country. Prof. Musaeva's research reputation is based mainly on her works on agricultural economics and problems of economic growth and development of the transitional economy of Kyrgyzstan, which was ended with the formation of the idea of the Asian model of economic reforms. She was involved in several significant research initiatives and projects as part of the growing concern about economic reforms, strategy of economic development and their likely impact on the transitional economy of Kyrgyzstan, where the choice of the liberal model of economic reforms was natural and determined by the specific socio-economic and cultural-historical features of the development of the Kyrgyz people as a result of the nomadic lifestyle. These followed by the formulation and interpretation of the Asian model of the economic reforms in Kyrgyzstan and its future development trends.
\end{abstract}

Keywords: Economics, Asian model, Economic reforms, Transition Economy, the Kyrgyz Republic, Female Economist, Eurasia

JEL Code Classification: A2, B4, O1, P2, Q1

UDC: 330(338.1)

DOI: https://doi.org/10.17015/ejbe.2019.024.05

\footnotetext{
* Ph.D., Assistant Professor, Ala-Too International University, Bishkek, Kyrgyzstan. Email: nargizalymkulova@gmail.com 
Tracing the Economic Transition of Kyrgyzstan in the Works of Prof. Dzharkinay Asanovna...

\section{Introduction}

Professor Musaeva Dzharkinay Asanovna (1948-2018), an esteemed economist, passed away in Bishkek on December 16, 2018. Prof. Musaeva was a renowned and well-respected academic nationally and internationally, and a wonderful mentor to her colleagues and students. A pioneer in her field, Prof. Musaeva used a historical, logical approach to unify and find the reasons for the particular issues which were related to the Ph.D. Students dissertation topics. She shepherded the empirical revolution in writing the dissertation works in Economics in the Kyrgyz Republic, using empirical approach to tackle some of the country's toughest issues. She brought this approach into the Dissertation Council of the Republic and into Ala-Too International University, where she educated, inspired hundreds of students and lecturers in her more than 47-year teaching tenure.

Dzharkinay Asanovna Musaeva - doctor of economics, a professor, graduated from Moscow State University named after M. Lomonosov in 1971. Prof. Musaeva's research reputation is based mainly on her works on agricultural economics and problems of economic growth and development of the transitional economy of Kyrgyzstan, which was ended with the formation of the idea of the Asian model of economic reforms. As she mentioned later: "Throughout my long life, I was engaged in research of issues that were related to the actual problems of economic development of the country. At the beginning of the scientific activity, which fell on the student years at Moscow State University, as the main topic of research, I choose to study the issues of Agricultural Economics. Within the walls of the University, the agrarian theme was considered unfashionable. In those days, the actual problems were topics related to the study of the industry. However, since our Republic was predominantly agrarian, the purpose of my research was the problems of agricultural economic development. One of the important problems of the Soviet economy in those days (the 1970s) were the problems associated with the inefficiency of the economy" (Musaeva \& Bekbolotova, 2018b). In 1979 Prof. Musaeva completed her candidate sciences degree at the Kyrgyz Academy of Sciences and defended her dissertation.

Prof. Musaeva has served in editorial board member of the Eurasian Journal of Business and Economics for a long-time since the first issue of the journal. She held the position of the Chair of the Dissertation Council at the National Academy of Sciences and was Chair of the Expert Council of the Higher Attestation Commission of the Kyrgyz Republic. She had participated in several international projects.

Prof. Musaeva said, "In recent years, my research has begun to be supplemented by the research of my students. Since a significant part of my time has always been devoted to the teaching and preparing of young scientists and experts, " in 2018, a short time before she passed away. Her example is one that all economists and scholars should emulate, not only as academics but also as human beings. Prof. Musaeva is the Professor who had an impact on training scholars with her sense of 
purpose, which had a profound impact on our trajectory, as well as many others. She is a true inspiration for many around the world.

\section{Scientific Contribution of Prof. Musaeva to the Literature}

The 1970s and 1980s may be characterized as involving the liberalization of the Soviet system, the renunciation of socialism on the Stalinist model, and an increase in incomes among the population, which meant the emergence of demand for quality agricultural products (Fanisovich, 1996). Throughout the Soviet times, Kyrgyzstan was as agrarian supplier for the USSR (Lee, 2019), whereas the inefficiency of the economy was considered as one of the crucial problems for the Soviet economy in the 1970s (Musaeva \& Bekbolotova, 2018b).

The development of inter-farm cooperation and agro-industrial integration was considered to be the critical direction of improving the efficiency of the agricultural economy during that time. In her works, particular attention was paid to economic problems of cooperation and integration (Musaeva, 1980a), especially, to problems of the improvement of agro-industrial complex structure (Musaeva, 1983a); to the role of agricultural cooperation in increasing the effectiveness of production (Musaeva, 1982), likewise to the development of cooperation and agro-industrial integration and implementation of the USSR Food Program (Musaeva, 1983b) and in the production of sugar-beet seed (Musaeva, 1984a). Notwithstanding, Prof. Musaeva attempted to provide insights and methodical recommendations on the development plan of cooperation and agro-industrial integration in the region and oblast agro-industrial unions as a part of the Ministry of agriculture of USSR (Musaeva, 1984b). Her research covered the issues of strengthening the intensification of agro-industrial production in the Soviet Kyrgyz Republic (Musaeva, 1986a, 1986b). In this line, Prof. Musaeva published a series of papers related to issues on profit distribution in cooperatives and their improvement regarding the economic incentives (Musaeva, 1979a, 1980b) and principles of formation of agroindustrial unions (Musaeva, 1979b). Remarkably, during the 1979s and 1990s, she underwent internships in the High school of Agro-Industrial Complex in Moscow (September 1985-February 1986) and in the High School of Economics in Sofia, Bulgaria (1985-1986). During that period, she served as the Head of Department at Institute of the Economy of Agriculture (September 1976-June 1980) and Associate Professor at Institute for Improvement of Qualification of National Economy Managers (June 1980- February 1989).

Prof. Musaeva stated that the methods and practices of planning and incentives were not enough to direct kolkhozes and sovkhozes, and other enterprises and organizations of agro-industrial complex to make better use of its agricultural potential, to encourage the active introduction of scientific achievements and best practices, to reduce losses of production process at all stages, including storage and processing, to address the problems of social reconstruction of the village. She saw the experience of Bulgarian Agro-industrial complex development as the solution to 
this problem and proposed the possibilities of its implementation in the Soviet Kyrgyz Republic (Musaeva, 1988a). Furthermore, Prof. Musaeva was brave enough through her works during the soviet time to provide some suggestions about optimal scales of agricultural enterprises (Musaeva, 1988b), further relying on this, she proposed the new system instead of an inefficient pyramid (Musaeva, 1988c); furthermore, the new form of agricultural enterprises to be adopted to increase the efficiency and effectiveness of the production (Musaeva, 1989). Later, Prof. Musaeva will state that this topic is currently among the insufficiently developed sections of modern economic science (Musaeva \& Bekbolotova, 2018b). In this light, a dedicated public servant, Prof. Musaeva, served as a consultant on economic reforms at the White House between February 1989-March 1989. The majority of her agrarian economy-related research looked at perspectives of multi structural economy development in Kyrgyz agriculture (Musaeva, 1990a, 1990b, 1990c).

After the collapse of the USSR, the independent Kyrgyz Republic started its transition to a market-based economy, which was followed by a breakdown of trade links with the Former Soviet Union republics and a surge of inflation, which further led to the shortage of necessary goods and services (Alymkulova \& Ganiev, 2019). Kyrgyzstan suffered a collapse in economic production that was among the most dramatic of those experienced by the former Soviet territories, and as a result of declines in industrial and agricultural production, by the mid-1990s, 20 percent of the population was effective without work (Huskey, 1995). With the beginning of perestroika, the most crucial problem for Prof. Musaeva was understanding of the mechanism of development of the transitional economy of Kyrgyzstan, the study of which has been devoted for many years. What should be highlighted is that the dramatic changes that occurred in Kyrgyzstan's agriculture during the transition from plan to market are perhaps best illustrated by the shifting role of agricultural enterprises and individual farms (Lerman \& Zedik, 2009). In this sense, for that period, Prof. Musaeva's primary research was focused on socialism and market (Musaeva, 1991a), on issues of the private sector formation (Musaeva, 1992, 1991b), and the potentials of the transition to a multi structural agrarian economy for the Kyrgyz Republic (Musaeva, 1991c). While presenting her paper at the 9th International Conference on USSR and East European Agriculture in Ciechocinek, Poland in 1990 she stated that steady development of the agricultural economy presupposes that transition to the multi-structured economy will be a complicated process and that it will require a relatively long transition period (Musaeva, 1990c). It was concluded that one of the main difficulties is that we did not have to build a new structure, but to restructure, re-make, re-organize already existing forms, which was more difficult. Since $96 \%$ of the arable land was assigned to collective and state farms (kolkhozes and sovkhozes), whereas 3.6\% was used for small household plots (Musaeva, 1991c, p.121). Based on her long-term research and scientific understanding of the transformational processes, she has brought an idea of the origins of the way to a market economy (Musaeva, 1992b) in line with the insights on the economic mechanism of the production system management of the economy 
(Musaeva, 1993). However, Kyrgyzstan is a republic in Central Asia that embarked on a reform program after independence in 1991 and has been struggling with structural impoverishment since (Ronsijn, 2006).

The Kyrgyz Republic embraced advice from western institutions and advocates of rapid change, and, within limits, its president fostered the emergence of the most liberal regime in the region (Pomfret \& Anderson, 2001). On one hand, mass and rapid privatization and 'shock therapy' brought by the Washington Consensus have been perceived as the pillars of change in the country. On the other hand, the reform was accompanied by several negative factors, including fast-growing unemployment, poverty, a sharp decline in industrial and agricultural output, and loss of foreign markets (Abazov, 1999). The independent Kyrgyz Republic is a relatively small landlocked country located in Central Asia. The country is surrounded by several large and growing markets, including Uzbekistan, Kazakhstan, Tajikistan, and China. Since 1994 Prof. Musaeva's focus of research has been the issues of economic growth and development of the transitional economy of the independent Kyrgyz Republic. She was greatly influenced by her studies in Western countries, especially in the United States. From December 1993 to June 1994, Prof. Musaeva was hosted at the University of Nebraska-Lincoln as a Fulbright Fellow, and one year later, she spent 12 months at the University of Kansas within the "partnership" program on economic development, the United States of America. Prof. Musaeva was invited to prepare and present a paper at the Salzburg Seminar. Later she would state that during her stay in the USA, she realized that our developing country has a chance to succeed, but it requires a lot to know a lot to learn. She determined the appraisal problems of different socio-economic systems (Musaeva, 1995a). Furthermore, she provided her view on priorities in the selection of the strategy of economic development in Kyrgyzstan (Musaeva, 1995b).

Prof. Musaeva was involved in several significant research initiatives and projects as part of the growing concern about economic reforms (Musaeva, 1997a, 1998a) and strategy of economic development (Musaeva, 1998b) and their likely impact on the transitional economy of Kyrgyzstan (Musaeva 1999,2000). These included an invitation in France by the University of Grenoble within educational program TEMPUS between April -May 1997 and April - May 1998. During that time, Prof. Musaeva served as a Head of Economics Department at the School of the Future Elite under the "Soros-Kyrgyzstan" Foundation (September 1996-July 2004). In 1999 she headed a project of World Bank on "Private sector development in rural areas" (Musaeva, 2001). The study was praised by an international expert panel and was published by World Bank. In 1998 she obtained a Doctor of Sciences in Economics degree from the National Academy of Sciences of the Republic of Kazakhstan. During that period, Prof. Musaeva served as a Head of the Economics Department of Kyrgyz State National University (September 1999-August 2007) and VIP professor of Teachex, EDNET, CARANA Corporation (May 2004-July 2007). 
Prof. Musaeva's research even extended into gender topics like the interplay between gender and strategy of economic development, the role of women in socioeconomic development, gender problems in economic theory, and women access to agricultural and economic resources in Kyrgyzstan ${ }^{1}$. These followed by the heading of the number of international projects under the Soros-Kyrgyzstan Foundation ${ }^{2}$ and the United Nations Development Program (UNDP) ${ }^{3}$. She had written a book on the subject titled "Gender and the Strategy of Economic Development of Kyrgyzstan" (Musaeva, 2003a).

Widely regarded in the 1990s as an 'island of democracy' in post-Soviet Central Asia (Anderson, 1999), by 2003 the small mountainous Republic of Kyrgyzstan found itself included alongside Côte d'Ivoire, Kenya, and Nigeria as 'candidates for failure' (Rotberg 2003, p. 20). In the aftermath of the March 2005, when an International Crisis Group (ICG) report described Kyrgyzstan as 'a faltering state' and warned that without significant international support 'there is a real risk that...the country will drift into irreversible criminality and permanent low-level violence' (ICG, 2005). In this light, Prof. Musaeva studied the factors of economic development and economic growth (Musaeva, 2003b, 2003c) and devoted her papers to the issues of economic reform failure in the Kyrgyz Republic (Musaeva 2007a, 2008a). The choice of the liberal model of economic reforms was natural and determined by the specific socioeconomic and cultural-historical features of the development of the Kyrgyz people as a result of the nomadic lifestyle (Musaeva, 2007a). She stated that it is necessary to concentrate efforts in the following areas: first of all, stimulation and support of domestic investments, effective use of foreign loans, stimulation, and support of organizations, structures with advanced technologies, producing value-added competitive goods and services (Musaeva, 2008). Prof. Musaeva's long-term studies of the experience of countries that have achieved great success, as well as the study of the socio-economic development of the Kyrgyz Republic, led to the conclusion that firstly, the competitiveness of domestic goods and services should be ensured; secondly, the integrated development of the village should be implemented.

"In our country, I would also start the process of rural development with the development of the processing industry," stated Prof. Musaeva (2007a). "Given the prerequisites and conditions for the development of our country, it can be concluded that the most appropriate model of reforms is the socio-democratic model, the difference of which would be "strong" government that would be able to adapt to the Soviet mentality to market relations by evolutionary means," marked Prof.

\footnotetext{
${ }^{1}$ Expert of the project «Women access to agricultural and economic resources," Kyrgyzstan. Sponsored by UNIFEM (UNDP), 2007.

2 Head of the project realization "Program of socio-economic development of a region" (by the example of Shopokov town, Gavrilovka village, Chuy oblast, Kyrgyzstan). Sponsored by the "Soros-Kyrgyzstan" Foundation.

${ }^{3}$ Expert of the project "Women access to agricultural and economic resources," Kyrgyzstan. Sponsored by UNIFEM (UNDP), 2007.
} 
Musaeva (2008b) later. Furthermore, Prof. Musaeva (2007b) highlighted political volition in practice (not orally) as one of the main requirements of task performance to raise the competitive capacity of domestic goods and services. She indicated three requirements to put the idea into practice: 1 - willingness, 2 - a group of enthusiasts, 3 - governmental and society' support.

In 2008 Prof. Musaeva released the book entitled "Theory and practice of transition economy." The book discusses the conceptual foundations of economic reforms, the fundamental reform models, the experience of economic reform, and the main reform patterns on the experiences of reform on the example of the particular countries: Poland, China, Russia, Kyrgyzstan. In the preface of the book she wrote the following: "With a few exceptions, the works of scientists of the transition period were rarely published (due to financial difficulties) and therefore, as a rule, did not reach their addressee including scientists-economists, young researchers, graduate students, politicians, practitioners, who had to study these ideas both from cognitive and polemic, to develop their views. Since the new ideas, approaches can not appear from scratch. They can be only developed based on criticism of other approaches. It can be considered is the only way in science that can help to develop their position. That served as the purpose of this work." (Musaeva, 2008c).

By the end of the twentieth century, the Kyrgyz Government had primarily succeeded in stabilizing the economy and establishing rudimentary market institutions (Kurmanalieva, 2008). The country's GPD regained its level of 1990 only in 2008, the period marked by the beginning of a severe and long-lasting global financial economic crisis, which soon spread across the world (Alymkulova \& Ganiev, 2019). Due to the underdevelopment of market relations, the economy of Kyrgyzstan experienced the negative consequences of the global crisis to a lesser extent than developed countries. However, the consequences of the global crisis can significantly complicate the socio-economic situation of the country, which has been already experiencing difficulties in transforming from a planned to a market economy (Musaeva, 2010). Notably, during the Global financial-economic crisis, in small open economies with floating exchange rate, including economy of the Kyrgyz Republic, national currency tends to depreciate, which in turn would cut import volume and remittances inflow, but in contrast, this leads to decrease in deficit of trade balance, which is positive effect of the Global crisis (Alymkulova, Atabaev \& Ganiev, 2016).

Furthermore, the two leading indicators of financial integration ${ }^{4}$ : volume- and equity-based measure coefficients are only 0.00096 and 0.005 , respectively (Musaeva \& Alymkulova, 2015). For instance, in developed countries, these indicators reached 2.5 in 2001 (Lane \& Milesi-Ferretti, 2003). The reasons for low financial coefficients for Kyrgyzstan are seen in undeveloped financial markets and low level of foreign investment inwards; the average FDI inflows to GDP ratio accounts for 4.61 percent. The asymmetric information in the debt market that flows

${ }^{4}$ Calculated based on Lane and Milesi-Ferretti (2003). 
on a global level cannot be taken lightly by the net suppliers of funds in the financial market in Kyrgyzstan in the light of the global financial crisis. In turn, it leads to a decline in FDI inflows, which merely depends on deposit fluctuations. As Musaeva and Alymkulova (2015) examined, a decrease in bank deposits by 1 percent leads to a 2.91 percent decline in FDI inflows. In this line, there are several studies of Prof. Musaeva that are devoted to the global financial-economic crisis impact on the economy of the Kyrgyz Republic (Musaeva, 2010a), and theoretical basis of the world economic crisis and its influence on socio-economic situation of the population in Kyrgyzstan (Musaeva, 2011a), post-crisis economic transformation in the Republic (Musaeva, 2010b). Similarly, Prof. Musaeva defined major strategies of successful development in the world economy, analyzed vital components of successful public development programs, including the economic development of South Korea, China (Musaeva, 2011a) to underline and to determine the main relevant approaches for the development strategy of the Kyrgyz Republic. More precisely, the systematic and comprehensive overview of the problems on the formation of strategy of development of the agro-industrial complex in the Kyrgyz Republic in the conditions of globalization (Musaeva, 2011c, 2014) were provided by Professor.

In the paper entitled "Conceptual bases of formation of the state policy of economic development of Kyrgyzstan for the future"(Musaeva, 2011d) which was published in Alatoo Academic Studies Prof. Musaeva will write that "the essence of this study is not a desire to criticize the strategy (Strategy of Economic Development of Kyrgyzstan for 2018-2020) posted on the site of National Statistical Committee of the Kyrgyz Republic ${ }^{5}$, but to try to give an alternative view on this problem." She tried to formulate an understanding of the goals and the mechanism of their achievement concerning Kyrgyzstan. Professor provided an understanding of the leading approaches of economic development as the ideas of "catching up" (sustainable) development, comparative advantage, and experience of the leading western countries. Furthermore, Professor addressed the problems of choice of socioeconomic development model within Central Asian economies (Musaeva, 2013d). In this sense, Prof. Musaeva analyzed and proposed her vision and understanding of the Strategy of Economic Development of Kyrgyzstan for 2018-2020. While Prof. Musaeva identified the primary goal to ensure the economic security of the country, she provided in detail the remaining steps to achieve it by the set objectives, tools, and criteria.

On October 26, 2011, President Nazarbayev outlined his vision of the Eurasian integration in Izvestiya ${ }^{6}$ with the title of "Eurasian Union: From the Conception to the History of the Future" (Sevim, 2013). Eurasian Economic Union was established in 2014, and Kyrgyzstan became a part of it in 2015. Prof. Musaeva discussed the issues of the Eurasian integration, its pros and cons (Musaeva, Bekbolotova \& Brovko, 2013a), and the insights of the optimal integration (Musaeva, 2013b) within

\footnotetext{
${ }^{5}$ http://212.42.101.124:1041/stat1.kg/index.php?option=com_content\&task=view\&id=27\&/temid=99

${ }^{6}$ Silk Road Economy \& Business Report, Newsletter, October 31, 2011.
} 
the impact of globalization on the transitional economy of Kyrgyzstan. The paper entitled "The trajectory of development of post-Soviet countries in the context of globalization: Asian model of economic reforms and the trajectory of its development" (Musaeva, 2013c) substantiates the features of socio-economic and cultural-historical development of Kyrgyzstan, which predetermined the choice of the model of economic reform, for the definition of which the author first introduces the concept of "Asian model." Whereas the natural consequence of economic reforms in these conditions is a transformational recession, falling living standards, growing discontent of the population. In the paper, Professor formulated the possible trajectories of the development of the Kyrgyz economy for the future. The concept of the "Asian model" reveals the reasons for the protracted transition period in the Kyrgyz Republic, including through the concept of path dependence ${ }^{7}$. Based on these reasons for the modern backwardness of the country's economy, the factors of economic growth of Kyrgyzstan in the future and the mechanism of economic strategy implementation will be formulated and presented during seminars, lectures, and conferences in the future.

Prof. Musaeva joined the Economics Department of Ala-Too International University (formerly International Ataturk Alatoo University) in September 2007, established and headed a unique Ph.D. program on Economics, which was called afterward as Musaeva's school of Economics by her colleagues and Stephen Frederick Starr, an American expert on Russian and Eurasian affairs, who has advised three U.S. presidents on Russian/Eurasian affairs. Within this program, she prepared seven candidates of sciences (Ph.D. students), who defended their dissertations in the National Academy of Sciences of the Kyrgyz Republic.

In 2016 Prof. Musaeva published a book entitled "Strategies of economic development of Kyrgyzstan through the eyes of young scientists" (Musaeva et al., 2016), which was co-authored with her first Ph.D. students of Ala-Too International University as a result of their Ph.D. dissertation works. The first part of the book is devoted to the Asian model of economic reforms and development. Whereas among the priority challenges facing developing countries in the context of globalization are the tasks of providing rich knowledge and training of STEM specialists, making efforts to ensure the competitiveness of national economies in the world market, improving the living standards of the population by increasing the share of products with high value-added production. The remaining part of the book covers the role of investments in the economic growth of the world economy in current conditions, prioritization of possible competitive industries based on the research method of hierarchies (Saati method), and private higher education in Kyrgyzstan. This, in line with the relevant items, should be included in the strategy of economic development for the Kyrgyz Republic.

\footnotetext{
7 Lecture on October 22, 2016, at American University of Central Asia, http://development.kg/index.html
} 
In 2018 Prof. Musaeva was invited by the Russian Academy of Sciences in Moscow, the Russian Federation, to prepare and present a paper on "Factors of economic development in the context of globalization" (Musaeva \& Bekbolotova, 2018a). Relying on Hogerndorn J.S. works, Professor identified the main five factors of economic development as the increase of productivity (investments to innovations and technical progress); development of agriculture; effective allocation of resources; growth of trade with foreign countries concerning comparative advantage; human resource development. Prof. Musaeva will state that this study is the completion of many years of research on economic development; some of the materials have already been published; some are published for the first time. In this study, she underlined if economic tools were singled out as a factor of development, then financial tools were not identified as such. This study provided the sixth factor of economic development as the formation of non-profit investment funds that would be targeted for raising funds for the economic development of the country.

The concluding work of Prof. Musaeva became the book which was co-authored with Dr. Salima Bekbolotova, "The Paradigm of Sustainable Development in the Age of Globalization" (Musaeva \& Bekbolotova, 2018b) published and presented in the International Conference on "Trajectory of Economic Development of Central Asian Countries in the Context of Globalization 2018" organized by the Institute of Economics of National Academy of Sciences of the Kyrgyz Republic, Research Center "Development" and Business Association "JIA" in Bishkek in November 2018. As Prof. Musaeva will state, this book is the result of multi-year joint research of two scientists of different generations, whereas some part of the book is the synthesis of previous ideas, and a significant part is the result of the new research on economic development. The book begins from the study on the welfare theory evolution with its sequence to the formation of present-day welfare theory. The authors defined the criteria to assess the level of economic development and the level of economic inequality in the Republic. The critical part of the book is devoted to the factors of economic development in the context of globalization. The reasons for the economic development of South Korea and China as the "Economic Miracle" were analyzed; the reasons for the failure of economic reforms in Ghana, and some Asian countries likewise were studied. The authors' formulation and interpretation of the Asian model of the economic reforms in Kyrgyzstan and its future development trends are discussed in the book. The specific features of the economic reforms, the formation of the agricultural and industrial policies in the Kyrgyz Republic in the context of globalization are debated. Furthermore, the main components and economic mechanism of the future development strategy of the Republic are presented.

Since all her time was devoted for the work with her Doctoral, Ph.D., master students and colleagues, furthermore while serving as a chair of the Dissertation Council on Economics of the Republic all the time she felt as this is her commitment to help and support young scholars especially scholars who came from the rural areas due to lack of qualitative education there. This brought an idea of the need to establish Public 
Fund Research Center "Development," ${ }^{8}$ whose activities would be entirely devoted to the study of economic growth and development of the economy of Kyrgyzstan. That idea matured gradually - with the accumulation of knowledge and experience, the training of many students who already knew a lot, and due to the extreme lack of research institutions in the country that would function in this field. Professor believed that mutual research would contribute to the economic development of Kyrgyzstan in the challenging conditions of globalization of the world economy. The Research Center "Development" has organized several international conferences, Inter-University Students' Olympiad on Economics and Young Scholars Contest.

\section{Views of Prof. Musaeva's Students}

Students of Prof. Musaeva D.A. will always fondly remember her for her teaching, her standing as a scholar and public figure. Her example is one that all economists and scholars should emulate, not only as academics but also as human beings.

"Prof. Musaeva was a unique person, who struggled to keep the science's reputation high, clean despite the hard times and hard conditions. She loved to share all that she knows with her students, and more importantly, listen to students in order to learn something new. Her approach to students was also unique - always took care of them like her children; knew almost everything about them: thesis, research developments, family, children, problems, challenges, etc.

Her sudden death made upset us, and we still cannot believe in it. We will miss her."

Dr. Bedelbai Mamadiev, Ph.D. student of Prof. Musaeva D.A. Director of Regional Institute of Central Asia

"If she took on something, she always tried to bring it to an end. Even in the case of her Ph.D. students, she studied problems and issues of their dissertation works with them together. Prof. Musaeva always demanded that Ph.D. students should study the issue, try to allocate time and effort. She always inspired us, guided us in the right direction, and somewhere, if we did not understand, she tried to help us. Prof. Musaeva was extremely persistent, never stopped; she was not afraid of any difficulties; she always motivated us, her Ph.D. students. She continually repeated that we should not be afraid of anything; only what we need to do is to go forward to achieve effective results.

Furthermore, the example of her works and research help us to reach that level. In other words, we can say she has raised a whole generation of young scientists who have analytical and critical skills. Even though she was always busy with scientific research, students, at the same time she taught, participated in various projects, always worked hard, she did not stop for a minute and continuously forced others to work in this direction too. That is her slogan as "never give up and go only forward." In one of the latest works with her Ph.D. students, she also directed and tried to

8 Official website of Public Fund Research Center "Development" is http://www.development.kg 
Tracing the Economic Transition of Kyrgyzstan in the Works of Prof. Dzharkinay Asanovna...

divide the economy into several sectors of the main ones that are of great importance for the Kyrgyzstani economy. Each dissertation work was devoted and covered the critical points of the strategy for the economic development of the Kyrgyz Republic. We can say the view of young scientists on the problems of the Kyrgyz economy is presented through the dissertation works of Prof. Musaeva's students."

Dr. Talant Asan uulu, Ph.D. student of Prof. Musaeva D.A. Director of Education and Quality Department and Head of Management Department, Ala-Too International University

"I am grateful to fate for the fact that I was able to learn from such an excellent Professor and scientist as Prof. Musaeva. She was my motivator, and I enjoyed working on my dissertation. Furthermore, thanks to working with Professor, we could win a project organized by Moscow State University and the World Bank on the "Assessment of Food Security of the Eurasian Countries."

Unfortunately, there are very few such influential scientists as she is today. Because she always sought to prepare scientists and experts who will have an impact on the future of the country. Besides, she was able by her actions to be an example for us to follow."

Dr. Nurlan Tokobaev, Ph.D. student of Prof. Musaeva D.A. Lecturer, International Kuwait University

"Prof. Musaeva was a kind, bright, and hard-working person. She was an example to her children, undergraduate, and graduate students. She inspired everyone with her example in work and life. She will always remain in our hearts."

Dr. Gulnaz Atabaeva, Ph.D. student of Prof. Musaeva D.A. Assistant Professor of Economics Department, Ala-Too International University

"I would like to express my sincere gratitude to the deeply respected Prof. Musaeva for her skill, high professionalism, sensitive attitude towards us, Ph.D. students. During our joint work, she taught me a lot, and her merit is also in the fact that she continued to believe in me even in those awkward moments on our hard way when I strongly doubted my abilities.

You could always turn to her for advice or share your problem. She tried to listen and suggest a way out.

An essential quality of the Professor's personality is the fullness of life force. This person respected the person in each of us, and most importantly - was able to see not only the shell formed by external circumstances, but also the deep, eternal essence, and helps it to manifest itself, to gain the necessary experience."

Turdukan Bekimbetova, Ph.D. student of Prof. Musaeva D.A. Lecturer of Management Department, Ala-Too International University 
"Prof. Musaeva had her unique approach to each of her students. She revealed us as individuals that we did not see in ourselves. In addition to the unique knowledge obtained from her, thanks to her, we managed to fulfill ourselves. In my case, having felt that I was striving for new knowledge, but not sure of my knowledge of the English language, she organized additional classes on the English language in one of the preparation groups for me. I am very grateful to her for her knowledge, faith in me, and constant motivation to become such a specialist who will be useful for the country and people."

Aizhan Kerimkulova, Master student of Prof. Musaeva D.A., Department of Economics, Ala-Too International University

\section{Conclusion}

Professor, doctor of Economics, Dzharkinay Asanovna Musaeva, the recipient of the outstanding scholar of National Education of the Kyrgyz Republic award, was a prominent representative of science and culture of the country. Prof. Musaeva, a member of the Fulbright, TEMPUS, Salzburg Seminar, and many others, was recognized for her studies in economics, particularly her researches in agricultural economics and problems of economic growth and development of the transitional economy of Kyrgyzstan, which was ended with the formation of the idea of the Asian model of economic reforms. Prof. Musaeva is a long-time Editorial Board member of the Eurasian Journal of Business and Economics since the first issue. She supervised and participated in the implementation of more than 30 international research projects, as part of the growing concern about economic reforms, strategy of economic development and their likely impact on the transitional economy of Kyrgyzstan, where the choice of the liberal model of economic reforms was natural and determined by the specific socio-economic and cultural-historical features of the development of the Kyrgyz people as a result of the nomadic lifestyle. These followed by the formulation and interpretation of the Asian model of the economic reforms in Kyrgyzstan and its future development trends. Prof. Musaeva has released nine monographs, over 70 scientific research publications, prepared ten candidates of sciences. She underwent repeated internships in the USA, France, Russia, Austria, Poland, Bulgaria, and Taiwan. Prof. Musaeva held the position of the Chair of the Dissertation Council at the National Academy of Sciences, was Chair of the Expert Council of the Higher Attestation Commission of the Kyrgyz Republic.

Dzharkinay Asanovna Musaeva had such remarkable range and breadth. She was insightful and so firmly on the side of seeking the truth. Prof. Musaeva is the Professor who had an impact on training scholars with her sense of purpose, which had a profound impact on our trajectory, as well as many others. She is a true inspiration for many around the world. 
Tracing the Economic Transition of Kyrgyzstan in the Works of Prof. Dzharkinay Asanovna...

\section{References}

Abazov, R. (1999). Economic migration in post-Soviet Central Asia: the case of Kyrgyzstan. Post-Communist Economies, 11(2), 237-252. https://doi.org/10.1080/14631379996002

Alymkulova N., Atabaev N., \& Ganiev J. (2016). Var - analysis of Global financial economic crisis impact on public budget and unemployment: evidence from the economy of the Kyrgyz Republic. Economy of Region, 12 (4), 1090-1101. https://doi.org/10.17059/2016-4-11

Alymkulova, N., \& Ganiev, J. (2019). Global financial-economic crisis transmission on the transition economy: Case of the Kyrgyz Republic. Journal of Financial Economic Policy, Vol. ahead-of-print No. ahead-of-print. https://doi.org/10.1108/JFEP-09-2018-0133

Anderson, J. (1999), Kyrgyzstan: Central Asia's Island of Democracy? The Netherlands: Harwood Academic Publishers.

Fanisovich, A. R. (1996). The balkanization of the economy of the Central Asian republics and its impact on the non-state sector. International Journal of Urban and Regional Research, 20(4), 744-753.

Huskey, E. (1995). The rise of contested politics in Central Asia: elections in Kyrgyzstan, 198990. Europe-Asia Studies, 47(5), 813-833. https://doi.org/10.1080/09668139508412289

ICG (2005), Kyrgyzstan: A Faltering State, International Crisis Group, Asia Report 109, December 16, 2005.

Lane, P.R. \& Milesi-Ferretti, G.M. (2003). International financial integration. IMF Staff Papers, Special Issue 50, 82-113. https://doi.org/10.2139/ssrn.495625

Lee, C. Y. (2019). FDI and Its Significance on Economic Development in Developing Countries: A Case of Kyrgyzstan with Issues and Suggestions. International Journal of Business Marketing and Management, 4 (1), 20-34.

Lerman, Z., \& Zedik, D. (2009). Agrarian reform in Kyrgyzstan: Achievements and the unfinished agenda (No. 888-2016-65098), 1-24.

Kurmanalieva, E. (2008). Empirical analysis of Kyrgyz trade patterns. Eurasian Journal of Business and Economics, 1 (1), 83-97.

Musaeva D.A. (1979a). Some questions about profit distribution in cooperatives. Republican scientific conference, Ministry of Kyrgyz Republic. Bishkek.

Musaeva D.A. (1979b). Principles of formation of agro-industrial unions. Improvement of revenue distribution among members of cooperation. Bishkek: Znanie.

Musaeva D.A.(1980a). Economic problems of cooperation and integration. Bishkek: Kyrgyzstan.

Musaeva D.A. (1980b). About the improvement of economic incentives in cooperatives. Bishkek: Ilim.

Musaeva D.A. (1982). The role of agricultural cooperation in increasing the effectiveness of production. Sbornik Trudov of Kyrgyz agricultural institute, 1.

Musaeva D.A. (1983a). Some problems with the improvement of the agro-industrial complex structure. All-USSR scientific conference. Institute of Economics of Academy of Sciences, Moscow.

Musaeva D.A. (1983b). Development of cooperation and agro-industrial integration and implementation of USSR Food Program. Sbornik Trudov of Kyrgyz agricultural institute. 
Musaeva D.A. (1984a). Agro-industrial integration development in the production of sugarbeet seed. Sbornik Trudov of Kyrgyz agricultural institute.

Musaeva D.A. (1984b). Methodical recommendations to develop the plan of cooperation and agro-industrial integration in region and oblast agro-industrial unions. Ministry of Agriculture of the USSR, All-USSR agricultural research institute. Moscow.

Musaeva D.A. (1986a). Questions on strengthening the intensification of agro-industrial production in Kyrgyzstan. Proceedings of scientific and practical conference. The high economic institute named after Carl Marx. Sofia, Bulgaria.

Musaeva D.A. (1986b). Intensifikaciya na selsko-stopanskoto proizvodstvo v"rhuosnavata na nauchno-gekhnicheskiya progress. Sofijska Pravda, April 23, 1986. Sofia, Bulgaria.

Musaeva D.A. (1988a). Experience of Bulgarian Agro-industrial complex development and possibilities of its implementation in Kyrgyzstan. Izvestia of Kyrgyz Academy of Sciences, Seria Social sciences, 1, 9-17.

Musaeva D.A. (1988b). Some suggestions about optimal scales of agricultural enterprises. Sbornik trudov of All-USSR agricultural research institute. Moscow.

Musaeva D.A. (1988c). The system instead of a pyramid. Soviet Kyrgyzstan. July 9, 1988.

Musaeva D.A. (1989). New form of agricultural enterprises. Soviet Kyrgyzsta. June 24, 1989.

Musaeva D.A.(1990a). Primary agent of production in the agrarian economy. Sbornik trudov of Kyrgyz agricultural institute.

Musaeva D.A. (1990b). Agrarian economy: from cooperation - to integration. Journal Communist of Kyrgyzstan, 2.

Musaeva D.A. (1990c). Perspectives of multi structural economy development in Kyrgyz agriculture. Proceedings of the IX International conference on agriculture. Chehochinek. Poland. September 11-14, 1-8.

Musaeva D.A. (1991a). Socialism and Market. Sovetskaya Kirgizia. February 13, 1991.

Musaeva D.A. (1991b). Market and Social Security. Slovo Kyrgyzstan. December 25, 1991.

Musaeva D.A. (1991c). About Transition to Multistructural Agrarian Economy (Kyrgyzstan case study), Economicheskie Nauki, 10, 121-124.

Musaeva D.A.(1992a). Current problems of private-sector formation, Slovo Kyrgyzstan. June 24, 1992.

Musaeva D.A.(1992b). The Origin of the Way to Market. Biznesmen, Bishkek. October 7, 1992. Musaeva D.A.(1993). Economic Mechanism of Production System Management. Bishkek: Ilim. Musaeva D.A. (1995a). Appraisal Problems of Different Socioeconomic Systems. Slovo Kyrgyzstan. May 20, 1995.

Musaeva D.A.(1995b). About Priorities in Selection of the Strategy of Economic Development in Kyrgyzstan. Proceedings of the second conference of Kyrgyz-Slavic university.

Musaeva D.A. (1997a). Economic Agent and Dialectics of Development of Economic Mechanism Management. Bishkek: Uchkun.

Musaeva D.A. (1998a). Kyrgyzstan: The Strategy of Economic Development, Collection of articles: The humanities without ideology. Methodology of the concept of open society. Bishkek: Soros-Kyrgyzstan foundation, 3-8.

Musaeva D.A. (1998b). Economic Reforms in Kyrgyzstan. Market, Money, and Credit, 8. 
Tracing the Economic Transition of Kyrgyzstan in the Works of Prof. Dzharkinay Asanovna...

Musaeva D.A.(1999). Priorities of Kyrgyz Economic Development in Perspective. Sbornik Trudov: Economics of Central Asian countries: difficulties and prospects of development. Bishkek: llim.

Musaeva D.A. (2000). Peculiarities of Transition Economy in Central Asia: Kyrgyz model. Journal Vestnik KGNU, seria Economics, 2.

Musaeva D.A. (2001). Private sector development in rural areas. World Bank. Working Paper. Musaeva D.A. (2003a). Gender and the Strategy of Economic Development of Kyrgyzstan. Bishkek: the Soros-Kyrgyzstan Foundation.

Musaeva D.A. (2003b). Factors of economic development of Kyrgyzstan. Journal Reform, 3 (19).

Musaeva D.A. (2003c). Economic growth and development. Bishkek: Kyrgyz National University.

Musaeva D.A. (2007a). Kyrgyz economic reforms: Problems and Development Perspectives. Proceedings of the conference dynamic and Broad Economic modernization in Central Asia: Current Issues and Perspectives. Almaty, Kazakhstan. December 7, 2007.

Musaeva D.A.(2007b). Raising the competitive capacity of domestic goods and services is the primary task of Kyrgyz economy. Alatoo Academic Studies, 2 (1), 29-31.

Musaeva D.A. (2008a). Economic reforms of Kyrgyzstan: Problems and prospects of development. Journal Questions of Economics, 1.

Musaeva D.A. (2008b). Modern factors of economic development of countries in transition, Vestnik Instituta povisheniya kvalifikatsii gosudartsvennih sluzhashih Respubliki Tadjikistan. Proceedings of Scientific and Theoretical Conference, 75-83.

Musaeva D.A. (2008c). Theory and practice of economy in transition. Bishkek: Ilim.

Musaeva D.A. (2010a). The Theoretical Foundations of the Global economic crisis and its impact on the economy of Kyrgyzstan, Vestnik Instituta povisheniya kvalifikatsii gosudartsvennih sluzhashih Respubliki Tadjikistan, 4, 62-71.

Musaeva, D. (2010b). Post-crisis economic transformation in Kyrgyzstan. In C. Dijkema, K. Gatelier, I. Samson, J. Tercine (Eds.), Rethinking the foundations of the State, an analysis of post-crisis situations (pp. 291-306). Brussels: Editions Bruylant.

Musaeva, D. (2011a). Theoretical basis of the world economic crisis and its influence on SES (Socio-economic situation) of the population in Kirgizstan. Perspectives on Kyrgyzstan, IAAU, 40-46.

Musaeva D.A.(2011b) Key problems of forming public police for the economic development of the Krygyzstan. Vestnik Akademy of management under the President of Kyrgyzstan, 12, 229-236.

Musaeva, D.A. (2011c). Problems of formation of strategy of development of agroindustrial complex in the Kyrgyz Republic in the conditions of globalization. Alatoo Academic Studies, 6(2), 31-38.

Musaeva, D.A. (2011d). Conceptual bases of formation of the state policy of economic development of Kyrgyzstan for the future. Alatoo Academic Studies, 6(2), 16-26.

Musaeva, D., Brovko, N., Bekbolotova, S. (2013a). Strategic approaches to involvement of the Kyrgyz Republic in the integration processes. Alatoo Academic Studies, 8 (2), 141-156. 
Musaeva, D. (2013b). Eurasian integration: a customs union, the pros and cons, the optimal integration. Journal of Economics, 2 (16), 40-45.

Musaeva D.A. (2013c). The trajectory of development of post-Soviet countries in the context of globalization: Asian model of economic reforms and the trajectory of its development. Alatoo Academic Studies, 8 (2), 12-21.

Musaeva D.A. (2013d). Central Asia: problems of choice of socio-economic development model. Alatoo Academic Studies, 8 (2), 128-131.

Musaeva D.A. (2014). Problems of forming the strategy of developing the agro-industrial complex. Journal of Economics, 2 (17).

Musaeva, D., Alymkulova, N. (2015). Foreign Direct Investment as a Transmission Channel of Great Recession (Case of the Kyrgyz Republic). Alatoo Academic Studies, 3, 151-156.

Musaeva, D., Bekbolotova, S., Mamadiev, B., Asan uulu, T. (2016). Strategies of economic development of Kyrgyzstan through the eyes of young scientists. Saarbrucken: Lambert Academic Publishing.

Musaeva, D., Bekbolotova S. (2018a). Factors of economic development in the context of globalization. Big Eurasia: Development, security, cooperation, 1 (2), 448-452.

Musaeva, D.A., Bekbolotova, S.M. (2018b). Paradigm of Sustainable Development in the Age of Globalization. Bishkek: Mega Print.

Pomfret, R., \& Anderson, K. (2001). Economic development strategies in Central Asia since 1991. Asian Studies Review, 25(2), 185-200. https://doi.org/10.1080/10357820108713304

Ronsijn, W. (2006). Coping during transition in rural areas: The case of post-Soviet southern Kyrgyzstan. Conflict Research Group, 4.

Rotberg, R.I. (2003), 'Failed states, collapsed states, weak states: Causes and indicators,' in Rotberg, Robert I. (ed.), When States Fail: Causes and Consequences, Princeton, NJ: Princeton University Press, (pp.1-25). https://doi.org/10.1515/9781400835799-003

Sevim, T.V. (2013). Eurasian Union: an Utopia, a Dream or a Coming Reality? Eurasian Journal of Business and Economics, 6 (12), 43-62.

\section{Appendices}

\section{Appendix 1. Participation of Prof.Musaeva D.A. in International Activities and Projects:}

- Project, Food Security in Central Asian Countries. 2014. World Bank and Moscow State University

- Scientific forum "Academic innovative initiatives "Science and the national interest." National Academy of Sciences. of KR. Bishkek. December 10-11, 2013.

- International scientific-practical conference "Problems and prospects of Economic Development of Central Asian Countries in the Context of Globalization. October 11, 2013. IAAU. Bishkek.

- Nominee of The World Cup Competition of Kyrgyzstani "Ideological breakthrough." Fund innovative initiatives. 2013. Bishkek.

- Round table "Eurasian Integration: CUSTOMS UNION. Pros and cons, optimal integration". Fund innovative initiatives. June 11, 2013. Bishkek. 
Tracing the Economic Transition of Kyrgyzstan in the Works of Prof. Dzharkinay Asanovna...

- V. International Forum of partner countries in the field of training and retraining for the state and municipal services. Scientific Conference. Sponsored by Hanns Seidel Foundation. December 17-18, 2010. Bishkek.

- Participation in international conference "Rossiya i mir: Vyzovy novogo desyatiletiya", Moscow. January 21-23, 2010. Russia.

- Participation in international research conference "Post - Crisis States Transformation: Rethinking the foundations of the State," Linkoping, Sweden. May 1-5, 2009. Sponsored by the "European Science Foundation." Expert of the project «Women access to agricultural and economic resources," Kyrgyzstan. Sponsored by UNIFEM (UNDP), 2007.

- Participation in the international seminar "Russian program for economic researches", Moscow, Russia. Sponsored by CONSORTIUM. February 1-7, 2001.

- Participation in International seminar "Role of women in socio-economic development", Almaty, Kazakhstan. Sponsored by the "Soros-Kyrgyzstan" Foundation. September 2001.

- Head of the project realization "Program of socio-economic development of a region" (by the example of Shopokov town, Gavrilovka village, Chuy oblast, Kyrgyzstan). Sponsored by the "Soros-Kyrgyzstan" Foundation.

- Head of the project realization "Reforming the system of business education in KR". Sponsored by the "Soros-Kyrgyzstan" Foundation, The Eurasia Foundation, May 2002.

- Head of the international project realization of Soros-Kyrgyzstan foundation in association with Russian Economic School (Moscow) "Gender and strategy of economic development of Kyrgyzstan". Sponsored by the "Soros-Kyrgyzstan" Foundation, 2002-2004.

- Organization and realization of international seminar "Gender problems in economic theory" in the framework of associated project of Woman program of Soros-Kyrgyzstan Foundation and Kyrgyz National University. Sponsored by the "Soros-Kyrgyzstan" Foundation, Bishkek. January 28-29, 2004.

- Participation as a member of Board of directors in Central Asian Center for higher education. Sponsored by the Soros-Kyrgyzstan Foundation, Almaty, Kazakhstan, 2002-2004.

- Project CARANA Corporation "Education Network Academy" as a VIP Professor, May 2004 August 2007, USAID.

- Participation as a VIP Professor in the project of CARANA Corporation "TeachEx" at the Educational Network Academy (ACCELS/CARANA), 2007, USAID.

- Participation in international project "Collaborative training of scholars (Ph.D. students)" in association with the University of Grenoble (France). September, 2004-2006.

- Project "The School of Future Elite" as a tutor. "Soros-Kyrgyzstan" Foundation. 1996 - 2002.

- Participation in the Partnership project organization for MBA educational program development in association with the University of Florida. Sponsored by the American government, the Soros-Kyrgyzstan Foundation, 2000.

- Participation in the project "Reforming the system of business education in KR," Center of magistracy, post-graduate study, and national educational programs of Kyrgyz National University. Grant AO1-7143 The Eurasia Foundation, August 3 - February 3, 2002.

- Project: "Impact analysis of the types of property on the performance of agricultural enterprises (Case of three Central Asian Republics)". Grant \#: ROO-4421. In "Economic education and research Consortium Russia grant competition' in 2000-2001. The Eurasia Foundation (Moscow).

- Executive Manager in Project: "The Kyrgyz Republic: Private Sector Development In Rural Areas". Supported by the World Bank, 1999-2000. 
- Grant agreement No. IA-260-99-19G between DjarkinayMusaeva, Institute for Integration of International Programs, Kyrgyz State National University, and the United States of America, represented by Edward Kulakovski, PAO USIS Bishkek, given for publishing abstracts from the student conference "Economics of Central Asia: Difficulties and Perspectives." May 1999 January 2000.

- Participation in The International conference «Les trajectories de transition a l'est: Mesures, typologies, differenciations et interpretations», 10-11 Decembre 1999. Groupe Transition development - Espace Europe. Universite Pierre Mendes France. Grenoble. France.

- Participation in Central and East Europian Forum. The seminar on Central Asia issues. Sponsored by Batory Foundation. June 15-21, 1998. Warsaw, Poland.

- Participation in the TEMPUS program "Reforming of high education." University of Grenoble, France. Kyrgyz-European Faculty, Institute for Integration of International Educational Programs, Kyrgyz National University. Sponsored by European Community, 1996 - 1999.

- Salzburg Seminar, Session 321, February 15-22, 1996, "Transition economy." A grant awarded by the Nippon Foundation Endowment Funds Program.

- Fulbright Scholar Program. Research Award in the United States. Project "Development of the Agro-Industrial Complex of Kyrgyzstan during the Transition to a Market economy", 1995-1996, University of Kansas, Lawrence, USA.

- Participation in the Partnership project realization for BBA educational program development in Kyrgyz-American faculty, Kyrgyz National University, in association with the University of Nebraska-Lincoln. Internship at the University of Nebraska-Lincoln, December 1993 - June, 1994.

- International Conference "Restructuring food and agricultural systems in Central Europe and the USSR: strategies for policy, investment, and assistance." Paper: "On Priorities in Development of Transitional Economy in the Agro-Industrial Complex of the USSR." October 21-23, 1990, Budapest University, Hungary. Sponsored by the Ford Foundation.

- Ninth International Conference on USSR and East European Agriculture. Paper: "Prospects for Development of Multistructured Economy in the Agro-Industrial Complex of Kirgizia (USSR)" sponsored by the Ford Foundation. Ciechocinek, Poland, September 11-14, 1990.

- Internship in the University of K. Marx "Experience of the Agro-industrial complex development in Bulgaria and possibilities of its implementation in Kyrgyz SSR." Sofia, Bulgaria, November 1985 - August 1986.

\section{Appendix 2. List of the Selected Publications of Prof. Musaeva D.A.}

- Musaeva, D.A., Bekbolotova, S.M. (2018). Paradigm of Sustainable Development in the Age of Globalization. Bishkek: Mega print.

- Musaeva, D., Bekbolotova S. (2018). Factors of economic development in the context of globalization. Big Eurasia: Development, security, cooperation, (1-2), 448-452.

- Musaeva, D., Bekbolotova, S., Mamadiev, B., Asan uulu, T. (2016). Strategies of economic development of Kyrgyzstan through the eyes of young scientists. Saarbrucken: Lambert Academic Publishing.

- Musaeva, D. (2016). Vyzovy razvivayushchihsya ekonomik v usloviyah globalizacii. International Conference Proceedings, Focus on Economics: Lessons for Development, 40-46.

- Musaeva D.A., Azhykulova A.A. (2015). The Effectiveness of Fiscal Policy and its Assessment System in the Modern Conditions". Musa Ryskulbekov Kyrgyz Economic University Vestnik, 4 (34), 47-50. 
Tracing the Economic Transition of Kyrgyzstan in the Works of Prof. Dzharkinay Asanovna...

- Musaeva, D., Alymkulova, N. (2015). Foreign Direct Investment as a Transmission Channel of Great Recession (Case of the Kyrgyz Republic. Alatoo Academic Studies, 3, 151-156.

- Musaeva D.A., (2015). The challenges of developing economies in a globalizing world. Alatoo Academic Studies, 4, 127-135.

- Musaeva D.A. (2014). Problems of forming the strategy of developing the agro-industrial complex. Journal of Economics, 2(17).

- Musaeva D.A. (2013). The trajectory of development of post-Soviet countries in the context of globalization: Asian model of economic reforms and the trajectory of its development. Alatoo Academic Studies, 8 (2), 12-21.

- Musaeva D.A. (2013). Eurasian integration: a customs union, the pros and cons, the optimal integration. Journal of Economics, 2, 40-45.

- Musaeva D.A. (2013). Central Asia: problems of choice of socio-economic development model. Alatoo Academic Studies, 8 (2), 28-131.

- Musaeva, D., Brovko, N., Bekbolotova, S. (2013). Strategic approaches to involvement of the Kyrgyz Republic in the integration processes. Alatoo Academic studies, 8 (2), 141-156.

- Musaeva D.A. (2011). Critical problems of forming public police for the economic development of the KR. Vestnik Akademy of management under the President of Kyrgyzstan, 12, 229-236.

- Musaeva, D.A. (2011). Problems of formation of strategy of development of agroindustrial complex in the Kyrgyz Republic in the conditions of globalization. Alatoo Academic Studies, 6 (2), 31-38.

- Musaeva, D.A. (2011). Conceptual bases of formation of the state policy of economic development of Kyrgyzstan for the future. Alatoo Academic Studies, 6 (2), 16-26.

- Musaeva, D.A. (2011). Theoretical basis of the world economic crisis and its influence on SES (Socioeconomic situation) of the population in Kirgizstan. Perspectives on Kyrgyzstan, IAAU, 2011, 40-46.

- Musaeva D.A. (2010). The Theoretical Foundations of the Global economic crisis and its impact on the economy of Kyrgyzstan. Vestnik Instituta povisheniya kvalifikatsii gosudartsvennih sluzhashih Respubliki Tadjikistan, 4, 62-71.

- Musaeva, D. (2010). Post-crisis economic transformation in Kyrgyzstan. In C. Dijkema, K. Gatelier, I. Samson, J. Tercine (Eds.), Rethinking the foundations of the State, an analysis of post-crisis situations (pp. 291-306). Brussels: Editions Bruylant.

- Musaeva D.A. (2008). Modern factors of economic development of countries in transition. Vestnik Instituta povisheniya kvalifikatsii gosudartsvennih sluzhashih Respubliki Tadjikistan, Proceedings of Scientific and Theoretical Conference, 75-83.

- Musaeva D.A. (2008). Theory and practice of economy in transition. Bishkek: Ilim.

- Musaeva D.A. (2008). Economic reforms of Kyrgyzstan: Problems and prospects of development. Journal Questions of Economics, 1.

- Musaeva D.A. (2008). Integration and Economic Development in transition Economies. Proceedings of the International Congress, Conference Series 14, 88-93.

- Musaeva D.A. (2007). Raising the competitive capacity of domestic goods and services is the primary task of Kyrgyz economy. Alatoo Academic Studies, 2 (1), 29-31. 


\section{Nargiza ALYMKULOVA}

- Musaeva D.A. (2007). Kyrgyz economic reforms: Problems and Development Perspectives. Proceedings of the conference on Dynamic and Broad Economic modernization in Central Asia: Current Issues and Perspectives, 12-17.

- Musaeva D.A. (2007). The time for action. Slovo Kyrgyzstana, January 17, 2007.

- Musaeva D.A. (2005). How long would Kyrgyzstan be an agrarian country? Journal Vestnik $K N U, 2$ (1).

- Musaeva D.A. (2003). Factors of economic development of Kyrgyzstan. Journal Reform, 3 (19).

- Musaeva D.A. Economic growth and development. Bishkek: Kyrgyz National University.

- Musaeva D.A. (2003). Gender and the Strategy of Economic Development of Kyrgyzstan. Bishkek: the Soros-Kyrgyzstan Foundation.

- Musaeva D.A. (2010). Private sector development in rural areas. World Bank Working Paper.

- Musaeva D.A. (2000). Peculiarities of Transition Economy in Central Asia: Kyrgyz model. Journal Vestnik KGNU, seria Economics, 2.

- Musaeva D.A. (1999). Priorities of Kyrgyz Economic Development in Perspective. Sbornik Trudov: Economics of Central Asian countries: difficulties and prospects of development. Bishkek: Ilim.

- Musaeva D.A. (1998). Economic Reforms in Kyrgyzstan. Market, money, and credit, 8.

- Musaeva D.A. (1998). Kyrgyzstan: The Strategy of Economic Development. Sbornik Trudov: The humanities without ideology. Methodology of the concept of open society. Bishkek: Soros-Kyrgyzstan foundation, 3-8.

- Musaeva D.A. (1997). Economic Agent and Dialectics of Development of Economic Mechanism Management. Bishkek: Uchkun.

- Musaeva D.A. (1995). About Priorities in Selection of the Strategy of Economic Development in Kyrgyzstan. Proceedings of the second conference of Kyrgyz-Slavic University.

- Musaeva D.A. (1995). Appraisal Problems of Different Socioeconomic Systems. Slovo Kyrgyzstan, May 20, 1995.

- Musaeva D.A. (1993). Economic Mechanism of Production System Management. Bishkek: Ilim.

- Musaeva D.A. (1992). The Origin of the Way to Market. Biznesmen, 7 October 1992.

- Musaeva D.A. (1992). Current problems of private-sector formation. Slovo Kyrgyzstan, June 24, 1992.

- Musaeva D.A.(1991). Market and Social Security. Slovo Kyrgyzstan, 25 December 1991.

- Musaeva D.A. (1991). About Transition to Multistructural Agrarian Economy (Kyrgyzstan case study). Economicheskie Nauki, 10, 121-124.

- Musaeva D.A. (1991). Socialism and Market. Sovetckay Kirgizia, February 13, 1991.

- Musaeva D.A. (1990). Property: the need in ideological prejudice denying. Journal Kyrgyz Land, 11.

- Musaeva D.A. (1990). Lomat' ne stroit'. Zemlya Kirgizii, 2, 11-13. 
Tracing the Economic Transition of Kyrgyzstan in the Works of Prof. Dzharkinay Asanovna...

- Musaeva D.A. (1990). Perspectives of multi structural economy development in Kyrgyz agriculture. Proceedings of the IX International Conference on Agriculture, Chehochinek, Poland, September 11-14, 1990, 8.

- Musaeva D.A. (1990). Agrarian economy: from cooperation - to integration. Communist of Kyrgyzstan, 2.

- Musaeva D.A. (1990). Primary agent of production in the agrarian economy. Sbornik Trudov of Kyrgyz Agricultural Institute.

- Musaeva D.A. (1989). About the new form of agricultural enterprises. Soviet Kyrgyzstan, June 24, 1989.

- Musaeva D.A. (1988). System instead of pyramid. Soviet Kyrgyzstan, July 9, 1988.

- Musaeva D.A. (1988). Some suggestions about optimal scales of agricultural enterprise. Sbornik Trudov of All-USSR Agricultural Research Institute.

- Musaeva D.A. (1988). Experience of Bulgarian Agro-industrial complex development and possibilities of its implementation in Kyrgyzstan. Izvestia of Kyrgyz Academy of Sciences, Seria Social sciences, 1, 9-17.

- Musaeva D.A. (1986b). Intensifikaciya na selsko-stopanskoto proizvodstvo v"rhuosnavata na nauchno-gekhnicheskiya progress. Sofijska Pravda, April 23, 1986, Sofia, Bulgaria.

- Musaeva D.A. (1986). Questions on strengthening the intensification of agro-industrial production in Kyrgyzstan. Proceedings of Scientific and Practical Conference, High economic institute named after Carl Marx, Sofia, Bulgaria.

- Musaeva D.A. (1984). Methodical recommendations to develop the plan of cooperation and agro-industrial integration in region and oblast agro-industrial unions. Ministry of agriculture of USSR, All-USSR Agricultural Research Institute.

- Musaeva D.A. (1984). Agro-industrial integration development in the production of sugarbeet seed. Sbornik Trudov of Kyrgyz agricultural institute.

- Musaeva D.A. (1983). Some problems of the improvement of agro-industrial complex structure. All-USSR Scientific Conference, Institute of Economics of Academy of Sciences.

- Musaeva D.A. (1983). Development of cooperation and agro-industrial integration and implementation of USSR Food Program. Sbornik Trudov of Kyrgyz agricultural institute.

- Musaeva D.A. (1982). The role of agricultural cooperation in increasing the effectiveness of production. Sbornik Trudov of Kyrgyz agricultural institute, 1.

- Musaeva D.A. (1980). Economic problems of cooperation and integration. Bishkek: Kyrgyzstan.

- Musaeva D.A. (1980). About the improvement of economic incentives in cooperatives. Sbornik trudov. Bishkek: Ilim.

- Musaeva D.A. (1980). To improve economic interrelations. Journal Kyrgyz Agriculture, 8.

- Musaeva D.A. (1979). Principles of formation of agro-industrial unions, Improvement of revenue distribution among members of cooperation. Bishkek: Znanie.

- Musaeva D.A. (1979). Some questions about profit distribution in cooperatives. Republican scientific conference. Ministry of the Kyrgyz Republic, Bishkek. 